\title{
open OAccess
}

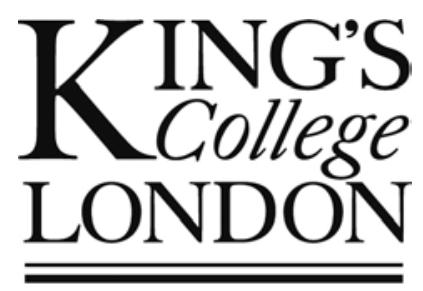

\section{King's Research Portal}

DOI:

10.1353/srm.2019.0033

Document Version

Peer reviewed version

Link to publication record in King's Research Portal

Citation for published version (APA):

Grande, J. (2020). London Songs, Glamorgan Hymns: Iolo Morganwg and the Music of Dissent. STUDIES IN ROMANTICISM, 58(4), 481-503. https://doi.org/10.1353/srm.2019.0033

\section{Citing this paper}

Please note that where the full-text provided on King's Research Portal is the Author Accepted Manuscript or Post-Print version this may differ from the final Published version. If citing, it is advised that you check and use the publisher's definitive version for pagination, volume/issue, and date of publication details. And where the final published version is provided on the Research Portal, if citing you are again advised to check the publisher's website for any subsequent corrections.

\section{General rights}

Copyright and moral rights for the publications made accessible in the Research Portal are retained by the authors and/or other copyright owners and it is a condition of accessing publications that users recognize and abide by the legal requirements associated with these rights.

- Users may download and print one copy of any publication from the Research Portal for the purpose of private study or research.

-You may not further distribute the material or use it for any profit-making activity or commercial gain

-You may freely distribute the URL identifying the publication in the Research Portal

\section{Take down policy}

If you believe that this document breaches copyright please contact librarypure@kcl.ac.uk providing details, and we will remove access to the work immediately and investigate your claim. 
Copyright (C) 2019 James Grande. This article first appeared in Studies of Romanticism 58:4 (Winter 2019). Reprinted with permission by Johns Hopkins University Press.

\author{
JAMES GRANDE
}

\title{
London Songs, Glamorgan Hymns: Iolo Morganwg and the Music of Dissent
}

This essay explores the relationship between song, political radicalism and religious dissent through the case of Iolo Morganwg (1747-1826), stonemason-poet, London showman and selfproclaimed preserver of the Welsh bardic tradition. In recent years, our understanding of Iolo Morganwg (the bardic name of Edward Williams; literally, "Ned of Glamorgan") has been transformed by the work of scholars including Mary-Ann Constantine, Ffion Mair Jones, Damian Walford Davies, Cathryn Charnell-White and Geraint Jenkins. ${ }^{1}$ Through a landmark series of publications from the University of Wales Press, Iolo has become a prominent voice within a reconfigured, archipelagic or "four nations" Romanticism. The present essay aims to build on this work by focusing on the role of song - a category used here to encompass political ballads, traditional melodies and dissenting hymns - in Iolo's career as it unfolded between London and South Wales. In doing so, it joins with other essays in this issue in suggesting the complexities of the transmission and circulation of song within and beyond national boundaries, in a way that complicates any straightforward centre-periphery model. My particular interest in Iolo is as a

\footnotetext{
${ }^{1}$ See Walford Davies, Presences That Disturb: Models of Romantic Identity in the Literature and Culture of the 1790s (Cardiff: University of Wales Press, 2002), Jenkins (ed.), A Rattleskull Genius: The Many Faces of Iolo Morganwg (Cardiff: University of Wales Press, 2005), Jenkins, Ffion Mair Jones and David Ceri Jones (eds), The Correspondence of Iolo Morganwg, 3 vols (Cardiff: University of Wales Press, 2007), Charnell-White, Bardic Circles: National, Regional and Personal Identity in the Bardic Vision of Iolo Morganwg (Cardiff: University of Wales Press, 2007), Constantine, The Truth Against the World: Iolo Morganwg and Romantic Forgery (Cardiff: University of Wales Press, 2007), Walford Davies and Lynda Pratt (eds), Wales and the Romantic Imagination (Cardiff: University of Wales Press, 2007), Jones, “The Bard is a Very Singular Character”: Iolo Morganwg, Marginalia and Print Culture (Cardiff: University of Wales Press, 2010) and Jenkins, Bard of Liberty: The Political Radicalism of Iolo Morganwg (Cardiff: University of Wales Press, 2012).
} 
figure who inhabits the intersections and contradictions between popular song and the culture of dissent, illuminating the contested place of music within the formation defined by Daniel White as the "Dissenting public sphere." ${ }^{2}$ The significance of song represents a thread that runs through Iolo's life, from the first book he remembered from his childhood - The Vocal Miscellany (1733), a two-volume collection "of above four hundred celebrated songs" - to the Unitarian hymns he wrote in his final years. ${ }^{3}$ Song connects his apparently disparate activities in London and Glamorgan, forming a vehicle for his political and religious radicalism. For Iolo, song could buttress the authority of his antiquarian discoveries, affirm his bardic persona and spread the cause of Welsh Unitarianism, recovering a lost oral culture while forging new forms of identity.

Before focusing on Iolo's own work, the first section of the essay outlines the equivocal place of music within the dissenting imagination, as at once central to nonconformist identities and a continual source of anxiety. While the Church of England banned congregational hymnsinging - as opposed to the chanting of psalms or the choral performance of hymns and sacred music - until 1820, dissenters and Methodists celebrated singing as an affective expression of faith and community. ${ }^{4}$ By the late eighteenth century, congregational singing had assumed an important role for the many and various Protestant groups united by little more than their shared refusal to conform to the Thirty-Nine Articles of the Church of England. The suspicion directed towards this form of communal worship intensified during the 1790s, with hymn-singing becoming one of a range of somatic practices tainted with enthusiasm in the eyes of conservative and Anglican commentators. As Jon Mee writes, "From Locke onwards enthusiasm had been presented as a contagious disease capable of rapidly infecting the lower orders. To many the

\footnotetext{
${ }^{2}$ White, Early Romanticism and Religious Dissent (Cambridge: Cambridge University Press, 2006), 11.

${ }^{3}$ See Jenkins, Bard of Liberty, 13.

${ }^{4}$ See Isabel Rivers and David L. Wykes (eds), Dissenting Praise: Religious Dissent and the Hymn in England and Wales (Oxford: Oxford University Press, 2011).
} 
Methodist revival seemed to be corroborating evidence of this weakness in the popular mind." Hymn-singing played a prominent role within the "psychopathology of enthusiasm," drawing believers together in a heightened emotional state: a symptom - their detractors claimed - of disturbed minds and bodies. ${ }^{5}$

It was not only their Anglican critics, however, who agonised over the status of music in dissenting culture. Dissenting writers themselves worried about the apparently irrational nature of music, its anti-mimetic qualities, or lack of semantic coding, as well as its vaunted power over the emotions and associations with both "popish" superstition and the rituals of what William Blake decried as "State Religion." For many nonconformists the sensuousness of music was indisputably at odds with dissenting austerity. As William Hazlitt, among the most merciless self-analysts of the dissenting character, wrote in 1815, a "distaste for pictures, music, poetry, and the fine arts in general" was part of the Puritan inheritance of rational dissent, a consequence (or so Hazlitt thought) of a dogmatic habit of mind and an "affected disdain" for the fine arts, "as not sufficiently spiritual and remote from the gross impurity of sense." $\mathrm{New}$ claims for the ideal nature of music began to emerge in this period, lifting music away from the senses, but these did little to alleviate such concerns. Indeed, within the generalised suspicion of music, instrumental music occupied an especially vexed status for dissenting writers. The so-called "rise of instrumental music" around 1800, linked to the importing of Austro-German repertoire and an accompanying proliferation of aesthetic theorizing, was often registered with irony or scepticism within the periodicals of the dissenting public sphere, including the Analytical Review (1788-98), London Magazine (1820-9) and Monthly Repository (1806-38). Indeed, the profoundly

\footnotetext{
${ }^{5}$ Mee, Dangerous Enthusiasm: William Blake and the Culture of Radicalism in the 1790s (Oxford: Clarendon Press, 1992), 49.

6 "On the Tendency of Sects," The Complete Works of William Hazlitt, 21 vols, ed. P.P. Howe (London: J.M. Dent, 1930-4), IV, 47-51 (49).
} 
ambivalent response of dissenting writers to new kinds of music from continental Europe goes some way to explaining the contradictions that mark the place of music in nineteenth-century Britain, at once ubiquitous and uncertain, and contributed to the view of Britain as an unmusical nation that was so firmly entrenched by the beginning of the twentieth century.

Debates about musical meaning were, then, both troubling and liberating for dissenters committed to the complete sufficiency of scriptural revelation and a biblical hermeneutics that extended to their own lives in a constant search for signs of divine election. Instrumental music frustrated the hermeneutic habits of dissent, even as divinely-inspired song held out the promise of a plenitude of meaning on the model of the biblical prophet or psalmist. While there is no doubt scope for work on the musical and auditory culture of every dissenting denomination (Baptists, Congregationalists, Presbyterians, Quakers...), we might identify two broad tendencies within the fractured, disputatious culture of Protestant nonconformity: millenarian enthusiasm, and rational dissent. The first of these might be characterized by political radicalism, claims to direct inspiration and antinomian refusal of the moral law. This is the milieu richly described by Leigh Eric Schmidt, who brings together religious history and the history of the senses to show how the musical culture and audible visions of evangelicals challenge the ocularcentric claims of the Enlightenment and the privileged place of visuality and the gaze within our narratives of modernity. ${ }^{7}$ In a similar vein, Misty Anderson argues that "Methodist hymn singing, more than any other single feature of their worship, exemplified the Methodist assault on Anglican liturgical identity, bringing sonic innovation, emotional intensity, and a participatory aesthetic of worship to the Methodist meeting." ${ }^{\prime 8}$ In contrast to earlier, more hostile accounts - most

\footnotetext{
${ }^{7}$ Schmidt, Hearing Things: Religion, Illusion, and the American Enlightenment (Cambridge, Mass.: Harvard University Press, 2000).

${ }^{8}$ Anderson, Imagining Methodism in Eighteenth-Century Britain: Enthusiasm, Belief \& the Borders of the Self (Baltimore: Johns Hopkins University Press, 2012), 171.
} 
notoriously E. P. Thompson's vivid descriptions of the "Chiliasm of despair," the "psychic processes of counter-revolution" and "the box-like, blackening chapels ... like great traps for the human psyche" - Anderson emphasizes the "potential pleasures of the psychological release from the burdens of cognitive isolation that are part of these hymns." ${ }^{\text {"9 }}$ When it comes to the possibilities of song, Methodists and radical antinomians turn out to have a surprising amount in common.

If enthusiasm represents one side of the story of music and the dissenting sensorium, the alternative tendency can be traced through the supremely articulate networks of rational dissent or Unitarianism - always tiny in numerical terms, but well-represented through the prominent position of Unitarians in publishing and intellectual life. In this avowedly rational, progressive culture, music could embody dissenting ideals of sociability, conversational exchange and cosmopolitanism. However, music also appeared as a more unsettling, even threatening, presence, contaminated by its associations with luxury, commerce, imposture and unreason. While rational dissenters such as Anna Laetitia Barbauld, Amelia Opie and Eliza Flower were prolific contributors to Unitarian hymnody, as well as to secular genres of sentimental song, essayists and diarists including William Hazlitt, Charles Lamb and Henry Crabb Robinson give a more sceptical commentary on musical life within the pages of dissenting periodicals and through their letters and diaries. ${ }^{10}$ As these examples suggest, this was, to a large extent, a gendered division, prefiguring the dominant role of female writers within Victorian hymnody.

\section{Fugitive Songs}

\footnotetext{
${ }^{9}$ Thompson, The Making of the English Working Class (London: Victor Gallancz, 1963), 388, 381, 368; Anderson, Imagining Methodism, 173.

${ }^{10}$ See James Grande, "On Tongues and Ears: Divine Voices in the Modern Metropolis," in Roger Parker and Susan Rutherford (eds), London Voices, 1820-1840: Performers, Practices, Histories (Chicago: University of Chicago Press, 2019), 137-57.
} 
Iolo Morganwg is a figure who exemplifies many aspects of the broad history of music and dissent outlined above, but also complicates it in revealing ways, from his perspective as a figure marginalized even within the community of London Welsh, to his status as a trailblazer of Welsh Unitarianism whose class status differed markedly from more "polite," middle-class and metropolitan forms of Unitarianism. He eludes the division between radical enthusiasm and rational dissent already outlined by virtue of being - somewhat unusually - a rational enthusiast, who enlists song as part of his creative national project.

Iolo's writing expresses myriad forms of opposition: to the slave trade, Pittite politics, the literary marketplace, the Established Church, Britain's war with France and what he saw as the inferior culture of North Wales, compared to his native Glamorgan. Over the course of his career, Iolo was a tireless champion of the cultural inheritance and all-round superiority of South Wales. Twentieth-century scholarship, however, revealed him to have also been a brilliant forger, who fabricated much of the poetry and song he claimed to have discovered in medieval manuscripts. These creative appropriations of the Welsh past survive to the present day: at the heart of the National Eisteddfod, an annual celebration of Welsh national belonging, lies a ceremony in which those deemed to have made an exceptional contribution to the Welsh nation, language and culture - from heroes of Welsh rugby to the most recent Archbishop of Canterbury - are initiated within the order of the Gorsedd of Bards of the Isle of Britain. This ritual, presided over by the archdruid, invokes medieval Wales but in fact goes back no further than the late eighteenth century and, more precisely, the ceremony Iolo organised and presided over on the summer solstice, 21 June 1792, in the incongruous surroundings of north London's Primrose Hill. $^{11}$

\footnotetext{
${ }^{11}$ The Gorsedd ceremony was incorporated into the National Eisteddfod in 1819, as the Eisteddfod movement came under the control of the Anglican church.
} 
Iolo had arrived in London the previous year, leaving his wife Margaret and young children behind in Glamorgan and moving to a city twice as populous as the whole of Wales, in which an estimated 20,000 people (around one in fifty of the population) were of Welsh origin. ${ }^{12}$ Wales may not have been the "Land of Song" it would become by the 1870s, when this phrase comes to refer to a tradition of male voice choirs, chapel choirs and four-part congregational singing, but music was already an important element within a burgeoning sense of national consciousness, energetically promoted by the Welsh diaspora. ${ }^{13}$ In 1784, Edward Jones, official harpist to George III, published Musical and Poetical Relicks of the Welsh Bards, a folio collection of music and song, prefaced by "An Historical Account of the Welsh Bards and their Music and Poetry." ${ }^{\prime 14}$ The frontispiece of the collection contains an engraving after Philip de Loutherbourg's painting of Thomas Gray's The Bard (1757), showing the fabled last bard, the sole survivor of Edward I's massacre of the bards, dressed in druidic robes and playing a triple harp, cursing the invading Saxon troops from a wind-swept crag above the River Conwy, poised to plunge to his death. In the late eighteenth century, this most potent myth of the destruction of Welsh oral culture was being re-visited and symbolically reversed by Jones and his contemporaries. In his "Historical Account of the Welsh Bards," Jones claims "there is no living nation that can produce works of so remote antiquity, and at the same time of such unimpeached authority as the Welsh. ${ }^{15}$ He quotes the twelfth-century historian Gerald of Wales on the venerable Welsh tradition of singing in parts: Welsh singers "do not sing in unison, like the

\footnotetext{
${ }^{12}$ Emrys Jones (ed.), The Welsh in London, 1500-2000 (Cardiff: University of Wales Press, 2001), 55.

${ }^{13}$ See Gareth Williams, Valleys of Song: Music and Society in Wales, 1840-1914 (Cardiff: University of Wales Press, 1998). On the alnost exclusive focus on male voice choirs in the historiography, see Rachelle Barlow, "The 'Land of Song': Gender and Identity in Welsh Choral Music, 1872-1918” (unpublished Cardiff University PhD dissertation, 2015).

${ }^{14}$ See Joan Rimmer, "Edward Jones's Musical and Poetical Relicks of the Welsh Bards, 1784: A Re-Assessment," The Galpin Society Journal, 39 (1986), 77-96, and Mary-Ann Constantine, "The Relicks of Edward Jones," Romantic National Song Network, ed. Kirsteen McCue $<$ https://rnsn.glasgow.ac.uk/the-relicks-of-edward-jones/> [accessed September 26, 2019].

${ }^{15}$ Edward Jones, Musical and Poetical Relicks of the Welsh Bards (London, 1784), 1.
} 
inhabitants of other countries: but in many different parts. So that in a company of singers, which one frequently meets with in Wales, as many different parts and voices are heard, as there are performers." ${ }^{16}$ In the second volume, The Bardic Museum (1802), Jones celebrates the ancient bard in terms that anticipate such high Romantic accounts as Percy Shelley's Defence of Poetry (written 1821, published 1840):

The primitive British Bards constituted one of the most respected order of men in the ancient British states: they were the Fathers of Sciences; the national instructors, musicians, legislators, priest, prophets, and often princes. They assuaged savage men to knowledge, with their oratory, and polished human nature by their Music and Poetry. ${ }^{17}$

Iolo, however, was determined to subvert the work of Jones, the so-called "Bardd y Brenin" or "King's Bard": for him, Jones was a loyalist stooge, and Iolo's own interventions sought to promote the more radical aspects of Welsh culture and stress their availability as a cultural and political resource in the $1790 \mathrm{~s}$.

On previous visits to London, plying his trade as an itinerant stonemason, Iolo had made contact with the Gwyneddigion Society, founded in 1770 as a rival institution to the elite Honourable Society of Cymmrodorion. Meetings of the Gwyneddigion Society took place at the Bull's Head Tavern on Walbrook Street, with song, and specifically penillion-singing - vocal improvisation over a harp melody - an important part of proceedings. Through this society of Welsh expatriates, Iolo was introduced to the fourteenth-century poet Dafydd ap Gwilym, whose work was circulating in manuscript among Gwyneddigion members. Iolo began to compose his own poems in imitation, which he sent to Owen Jones and William Owen Pughe as the editors of Dafydd's works. Jones and Pughe unwittingly inserted them as an appendix to their edition, Barddoniaeth Dafydd ab Gwilym (1789), and Iolo's imitations were regarded for over a century as authentic fourteenth-century poems. This was the beginning of a prolific career of forgery,

\footnotetext{
${ }^{16}$ Jones, Musical and Poetical Relicks, 17.

${ }^{17}$ Edward Jones, The Bardic Museum, of Primitive British Literature (London, 1802), iii.
} 
which extended from print into performance. ${ }^{18}$ The first Gorsedd ceremony in 1792 claimed a similar continuity with medieval Wales. As Cathryn Charnell-White has shown, the publicity "echoed the extant proclamation scroll of the sixteenth-century eisteddfodau at Caerwys and noted that the aim of the proceedings was to appraise every poet who wished to be graded and licensed in music and poetry." 19 The aspiring bards recited their odes within a circle of twelve stones, part of "an intensely theatrical affair of gestures and proclamations, with great emphasis placed on the spoken word." ${ }^{, 20}$ Iolo conferred various druidic degrees - ovate, bard and druid and subsequently arranged for reports to appear in the Gentleman's Magazine, securing his reputation as a self-appointed leader of the bardic community.

Far from being an end in itself, however, Iolo used this position to bolster his identity as an English language poet, hoping to make his name and fortune in metropolitan literary culture. By this point, as Bethan Jenkins writes, "Iolo had fashioned two very distinct personae to present to the public, one Welsh and the other distinctly Anglophone," at once the "final descendant of an ancient lineage of bardo-druids," and a labouring-class poet in the mould of Stephen Duck or Ann Yearsley. ${ }^{21}$ Iolo's Poems, Lyric and Pastoral appeared in two volumes in 1794, issued by the Unitarian publisher Joseph Johnson and boasting an impressive and eclectic list of subscribers, ranging from the Prince Regent to Thomas Paine, via such luminaries as Joseph Priestley, Anna Barbauld, Hannah More, George Washington and “HUMANITY's WILBERFORCE." Many of the poems are designated as songs, hymns and pastoral ballads, some to be sung to

\footnotetext{
${ }^{18}$ Marilyn Butler has claimed Iolo as "a literary forger of genius, altogether worthy to be ranked with Macpherson and Chatterton as a reconstructor of British literary prehistory." See Mapping Mythologies: Countercurrents in Eighteenth-Century Poetry and Cultural History (Cambridge: Cambridge University Press, 2015), 152.

${ }^{19}$ Charnell-White, Bardic Circles, 123.

${ }^{20}$ Mary-Ann Constantine and Elizabeth Edwards, “'Bard of Liberty': Iolo Morganwg, Wales and Radical Song," in John Kirk, Andrew Noble and Michael Brown (eds), United Islands?: The Languages of Resistance (London: Pickering \& Chatto, 2012).

${ }^{21}$ Jenkins, Between Wales and England: Anglophone Welsh Writing of the Eighteenth Century (Cardiff: University of Wales Press, 2017), 108.
} 
specified Welsh, English and Scottish airs, and the collection was buttressed by a paratextual panoply of pseudo-antiquarian notes, proclaiming its connection to a lost bardic past. As Marilyn Butler writes, "the poems are mediocre, but the footnotes arresting, for they announce the existence of an unbroken secret tradition of Bardism which appears at significant points to anticipate the French revolutionary assault on institutional Christianity."22 Bardism here becomes a vehicle for the radical Enlightenment, a kind of Celtic Illuminati.

Poems, Lyric and Pastoral was simultaneously a revival of ancient traditions and an intervention in the politics of the present. To take one example, Iolo's version of "God Save the King" is one of several radical re-writings of this song that appeared in the 1790s. In a volume dedicated to the Prince of Wales, it is described as "A Song of PROPHECIES, that will, it is hoped and believed by many, be fulfilled in the Reign of GEORGE THE FOURTH., ${ }^{23}$ A headnote adds:

This is also intended, till a better appears, as a substitute, which the pacific world wishes to see, for that old War Song of British Savages, which, by way of supplicating the ALMiGHTY, had the blasphemous expression of "scatter his enemies, and make them fall," instead of praying that their hearts might be changed, and all enmity rooted out of them, and which (horrid to relate) has lately, too frequently, and accompanied by the choral organ, rent the lofty vaults of places, that, in better though less enlightened ages, have been dedicated to the worship of the PRINCE OF PEACE.-Oh! Priestcraft!

While "God Save the King" was famously taken up in theatres during the Revolutionary and Napoleonic Wars, often provoking a hostile reaction from radicals in the audience, Iolo is especially critical of the conjunction of militant nationalism with the "choral organ" and "lofty vaults" of the Church of England. ${ }^{24}$ These "blasphemous" expressions are replaced with visions of peace, liberty and song:

Britons, that Peace adore, Bless'd as in days of yore,

\footnotetext{
${ }^{22}$ Butler, Mapping Mythologies, 152.

${ }^{23}$ Iolo Morganwg, Poems, Lyric and Pastoral, 2 vols (London, 1794), II, 132-5.

${ }^{24}$ On the ability of "God Save the King" to divide theatre audiences, sometimes leading to scenes of disorder, see Oskar Cox Jensen, Napoleon and British Song, 1797-1822 (Basingstoke: Palgrave Macmillan, 2015), 38-9.
} 
Carol from shore to shore,

God save the King.

By the penultimate verse, "Wars and oppression cease, / Tune we the songs of Peace...," a sentiment that is somewhat undercut on the manuscript of the song, now in the National Library of Wales, by the regicidal verses written crossways on the same sheet and attributed to a "Yorkshire Quaker" (Figure 1). This manuscript shows that "reason's new dawning day," in the third verse, was among the lines added as Iolo revised the lyrics, emphasizing the revolutionary association between peace, light and the dawn of a new age of reason. At the end of the published text, Iolo adds a note recounting the strange fate of the song, from manuscript into newspaper and sheet music:

Copies of the first hasty draught of this trifle, consisting then of three stanzas, were given to a few friends, by which means it found its way into some of the daily papers.GouldiNG, the ballad and fiddle-monger, of James street, Covent garden, claimed the Welsh Bard's little fugitive for his own, and set it to very dull music, after having mangled it to his mind.-At OXFORD, a bedoctored Song-wright, divesting it of its original pacific sentiments, pinned an additional stanza (like a dish-clout) to its tail, full of, doubtless very proper, severity against poor Tom Paine._Alas! poor Song!

The manuscript adds a date for Iolo's initial distribution of the song among his friends: "in the summer of 1792." The sequence of subsequent events points towards the political contestation and complex mediation of songs within metropolitan print culture. Both lyrics and tune can be manipulated, or "mangled," even with this most famous of songs. Goulding sets the text to "very dull music," suggesting not just a pedestrian arrangement but a new melody, before a "bedoctored Song-wright" in Oxford ("bedoctor'd Bard" in the manuscript, a provocative conflation of Anglicanism and Bardism) transforms the lyrical content. Through this process, the ideological content is repeatedly inverted, as a royalist anthem becomes first a hymn to peace and then anti-Paineite propaganda. Iolo is determined to make this history public, demonstrating 
to his readers the cultural and political work that songs perform through the mediations of print culture.

Against this public attempt to demystify the social life of song, one of Iolo's letters from same year as Poems, Lyric and Pastoral points to the role of song - the same song, even - in violence on the London streets. Writing to his compatriot Hugh Jones, Iolo gives a vivid description of the counter-revolutionary soundscape created by the demonstrations of John Reeves's Association for Preserving Liberty and Property against Republicans and Levellers:

All the whores and thieves of London are assembled about the fellow called Reeves and his fiddlers and faddlers in a mighty band, bawling and squawling, like the songs of caterwauling, "God-Save-the-King! Church and King for ever!" They press every one that passes by into this infernal service, crying to him, "Blast your eyes, cry Church and King, Church and King, damn your soul!" I jabber'd Welsh, squeaked out, "Church sans King," in as broken a manner as I could, and passed for a Dutchman with all but a Welshman or two, who laughed at me ... This detestable taking of God's name in vain by profane drunkards, infidels, knaves, fools, whores, pick-pockets and (what is still more despicable) placemen and pensioners, who acknowledge no God but self-interest, is not the way for either church or king to conciliate the affections of a rational man. I was amongst this king-ridden mob in real danger of my Life. They were egged on by parsons in abundance. ${ }^{25}$

As a "rational man," Iolo refuses to join the loyalist cacophony of the "Church and King" mob, despite the threats of violence that accompany their "caterwauling" songs. "Jabber'd Welsh" becomes a form of self-defence, one that is humorously acknowledged by witnessing members of the London Welsh community. Again, Iolo is especially critical of the role of the Established Church in fomenting this violence, the "detestable taking of God's name" and the parsons encouraging the "king-ridden mob." In contrast to Iolo's vision of peace, song is here linked to loyalist violence on the London streets.

Eight months later, on 4 February 1795, Iolo performed a song he had written, "Trial by Jury," at the Crown and Anchor Tavern, in front of an audience of 900 radical reformers

\footnotetext{
${ }^{25}$ Iolo Morganwg to Hugh Jones, London, 4 June 1794, Correspondence, I, 676-7.
} 
celebrating the recent acquittals in the Treason Trials of Thomas Hardy, John Horne Tooke and John Thelwall. The Crown and Anchor was a meeting place for both radicals and loyalists in the 1790s, home to numerous radical meetings and dinners but also the place where Reeves's Association was founded. ${ }^{26}$ Mary-Ann Constantine and Elizabeth Edwards have described Iolo’s performance here as a moment of self-realization: Iolo "became at this point most fully, and most publicly, the character for which he was best known in radical and literary circles in 1790 s London, 'Bard Williams' ... the 'Bard of Liberty.",27 No longer organising bardic meetings in open air or running the gauntlet of loyalist mobs on the street, Iolo was performing in a space usually occupied by much more elite musicians. The event was commemorated in broadside, “Trial by Jury, The Grand Palladium of British Liberty" (Figure 2), and while this record or memento includes only the lyrics, Iolo's papers contain a manuscript with the melody: "Song, written, and set to music, by Edward Williams, for the celebration of the Trial by Jury" (Figure 3). This informal, hastily written text suggests that the event was not a solo performance, containing as it does sections for horn and clarinet as well as solo voice. Based on the first few words of the song, scribbled below the opening notes, it appears that only the first few bars of music, up to the repeat, are required to sing the whole song, suggesting the rest was purely instrumental. If we read this manuscript as a working musical document, the basis for performance, it shows Iolo aspiring to a more complex form than the standard street ballad, creating a carefully crafted musical event for a radical culture enjoying its moment of greatest triumph.

\footnotetext{
${ }^{26}$ On the contested place of the Crown and Anchor within the 1790s public sphere, see Ian Newman, The Romantic Tavern: Literature and Conviviality in the Age of Revolution (Cambridge: Cambridge University Press, 2019), ch. 2, "Crown and Anchor Dreams: Sedition in the Strand".

${ }^{27}$ Constantine and Edwards, "Iolo Morganwg, Wales and Radical Song,", 63.
} 


\section{Rational Hymns}

Through his tavern performances, invention of the Gorsedd, and publication of Poems, Lyric and Pastoral, Iolo established a unique persona within the experimental, heavily performative culture of 1790s radicalism. However, his multiple identities as Welsh bard, aspiring poet and London showman were often in uneasy coexistence. His letters suggest that while his primary aim was to appeal to English readers, his publisher Joseph Johnson encouraged him to exaggerate the Welsh aspects of the collection, performing his bardic identity for an audience with an increasing appetite for popular antiquarianism and a cultivated taste for native genius. With this in mind, Iolo's bardic persona appears less as a freewheeling assembly of diverse elements of Welsh culture than as a persona he was forced to assume within the metropolitan marketplace. He was never on an equal footting with the writers and intellectuals of Joseph Johnson's circle, his fate in this respect resembling that similarly marginalised and eccentric figure, "Blake the Engraver." 28 Samuel Taylor Coleridge, writing to John Thelwall, conveys some sense of Iolo's position in the networks of metropolitan dissent, describing his treatment by William Godwin:

Poor Williams, the Welch bard - (a very meek man) brought the tear into my Eye by a simple narration of the manner in which Godwin insulted him, under the pretence of Reproof - \& Thomas Walker of Manchester told me, that his Indignation \& Contempt were never more powerfully excited than by an unfeeling and insolent Speech of the said Godwin to the poor Welch Bard. ${ }^{29}$

Beyond such personal slights, Poems, Lyric and Pastoral would influence the Lake Poets but Iolo received little credit. Even when he did, a tone of condescension persists, as in Robert Southey's faintly patronising tribute to Iolo's local knowledge in his epic Madoc (1805): Iolo, old Iolo, he who knows

\footnotetext{
${ }^{28}$ For a reading of how, in 1793-5, "both Iolo and Blake were presenting themselves as contemporary manifestations of ancient bardic genius," see Jon Mee, “'Images of Truth New Born': Iolo, William Blake and the Literary Radicalism of the 1790s," in Jenkins (ed.), A Rattleskull Genius.

${ }^{29}$ Coleridge to Thelwall, 13 May 1796, in Collected Letters of Samuel Taylor Coleridge: Volume I, ed. Earl Leslie Griggs (Oxford: Clarendon Press, 1956), 127.
} 
The virtue of all herbs of mount or vale, Or greenwood shade, or quiet brooklet's bed; Whatever lore of science, or of song, Sages and Bards of old have handed down. ${ }^{30}$

Even science and song, it seems, did not accord equal status within the Johnson circle, and Southey used Iolo's cherished belief in the Madogwys, a lost tribe of Welsh-speaking American Indians, descended from followers of the twelfth century Prince Madog ab Owain Gwynedd, for his own ends, constructing a defence of British imperialism in direct opposition to Iolo's antiimperial views.

Southey's appropriation of Iolo's "lore" represents one instance of the fate of "bardic nationalism" described by Katie Trumpener:

English literature, so-called, constitutes itself in the late eighteenth and early nineteenth centuries through the systematic imitation, appropriation, and political neutralization of antiquarian and nationalist literary developments in Scotland, Ireland, and Wales. The period's new genres (ballad collection, sentimental and Gothic fiction, national tale, and historical novel), its central models of historical scholarship and literary production, and even its notions of collective and individual memory have their origins in the cultural nationalism of the peripheries. ${ }^{31}$

In Trumpener's account, this activity amounts to an overall schema for the development of genres and emergence of English literature itself, through processes of internal colonialism and commodification of cultural nationalism. This process is seen most clearly in the contemporary vogue for collections of national airs and melodies, including Robert Burns's collaborations with James Johnson on The Scots Musical Museum (1787-1803) and George Thomson on A Select Collection of Original Scottish Airs (1793-1818), Thomas Moore's work with Sir John Andrew Stevenson and Henry Bishop on Irish Melodies (1808-34), Lord Byron and Isaac Nathan's Hebrew Melodies (1815), and Felicia Hemans and John Parry's A Selection of Welsh Melodies

\footnotetext{
${ }^{30}$ Southey, Madoc, 2 vols (London, 1805), I, 79.

${ }^{31}$ Trumpener, Bardic Nationalism: The Romantic Novel and the British Empire (Princeton: Princeton University Press, 1997), xi.
} 
(1822). Such collections, combining traditional melodies with new lyrics and arrangements, enjoyed huge commercial success; Celeste Langan has described their equivocal status as products of print capitalism, 'imported from the periphery' to metropolitan drawing rooms. ${ }^{32}$ While this suggests a straightforward movement from periphery to centre, Iolo resists such centripetal force, moving back to South Wales and going on to produce work that was not directed towards the metropolitan marketplace. He also strenuously resisted any attempt at political neutralization, even in the unforgiving conditions of Pitt's Terror.

By the mid-1790s, the commercial success that Iolo had hoped for with Poems, Lyric and Pastoral failed to materialize, and the political climate had turned against his brand of Bardic radicalism. No longer seen as a harmless antiquarian, Iolo was called in for questioning by the Privy Council and interrogated by William Pitt, Lord Grenville and Henry Dundas. ${ }^{33}$ His subsequent life has led Kenneth Johnston to number Iolo among the "unusual suspects" of the 1790s, whose careers were disrupted by the counter-revolutionary "reign of terror." ${ }^{34}$ In 1795, Iolo returned to the Vale of Glamorgan, where he became one of the founders of the South Wales Unitarian Society and continued to organise Gorseddau ceremonies on each solstice and equinox, holding them on various mountain tops around Glamorgan. These periodically attracted the attention of the authorities, and during the invasion scare of 1797 were actually suppressed by the Glamorgan Yeomanry.

\footnotetext{
${ }^{32}$ Celeste Langan, "Scotch Drink \& Irish Harps: Mediations of the National Air", in Phyllis Weliver (ed.), The Figure of Music in Nineteenth-Century British Poetry (Aldershot: Ashgate, 2005), 25-49. Langan argues that in such collections "the "national" is identified partly by its difference from print, by its identification with the remainder, "air," that print cannot fully capture' (30). In the context of burgeoning Scottish, Welsh, and Irish nationalism, collections of national song could act as the vehicles of anti-English sentiment but could also reinforce internal colonialism through the appropriation and commodification of cultural identity. See also Karen McAulay, Our Ancient National Airs: Scottish Song Collecting from the Enlightenment to the Romantic Era (Farnham: Ashgate, 2013) and Elizabeth Edwards, "'Lonely and Voiceless Your Halls Must Remain': Romantic-Era National Song and Felicia Hemans's Welsh Melodies (1822)", Journal for Eighteenth-Century Studies, 38.1 (2015), 83-97.

33 Jenkins, Bard of Liberty, 111.

${ }^{34}$ Johnston, Unusual Suspects: Pitt's Reign of Alarm and the Lost Generation of the 1790s (Oxford: Oxford University Press, 2013), 143.
} 
Iolo's main energies, however, were focused in two different directions. The first, more public, one was in the production of hymns to proselytize Welsh Unitarianism. A vividly selfdramatizing 1811 to his London friend, and fellow Unitarian, George Dyer describes the conditions under which these were produced:

I am here, in this sequestered part of the country, in a kind of prison. For five or six years I have not been able to lie down in bed, owing to my ashmatical complaint. I sit up all night in a chair. This adds considerably to the expence of fire, candle, \&c. and I am not able to go from home any where beyond the very circumscribed circle of my friends and acquaintances who know my occasion for, and of whom I am free to ask, the accommodation of a chair and a little fire (if in winter) for a night. Such a request where I am now known might excite unfavourable suspicions ... I seldom sleep more than an hour together at night, then wake and read or write. The worst circumstance is I can not as formerly amuse myself with my German flute. My breath entirely fails me. This is to me an unpleasant privation. I have of late years bestowed some of my time in writing some hymns for our Welsh Unitarian societies in the Welsh language. They have met with considerable approbation and many of them will be printed in about a year or two more. ${ }^{35}$

This sequestered position, a state approaching solitary confinement, seems to exist in stark contrast to the sociability and tavern singing of Iolo's days as a radical celebrity and London showman. At the same time, it is as self-consciously performative as anything he wrote in London: he is still playing the role of the political and religious exile, and song-writing remains central to this identity.

During these years, Iolo wrote 3,000 Welsh-language hymns and composed 300 hymn tunes, many of which were published in Salmau yr Eglwys yn yr Anialwch ("Psalms of the Church in the Wilderness," Merthyr Tydfil, 1812, 1827, 1834). ${ }^{36}$ This project appears to signal a decisive break in Iolo's career: a return from metropolitan to rural life, from English to Welsh, from cultural nationalism to religious consolation, and a turn away from radical politics.

However, it is the continuities that are perhaps most striking. As Butler observes, "Druidism or

\footnotetext{
${ }^{35}$ Iolo Morganwg to George Dyer, Flimston near Cowbridge, Glamorgan, 15 February 1811, Correspondence, III, 55-6.

${ }^{36}$ See E. Wyn James, "The Evolution of the Welsh Hymn," in Rivers and Wykes (eds), Dissenting Praise, 252.
} 
Bardism emerges in Iolo's description as something like his own Unitarianism," while also "akin to the rational religions of the French revolutionaries. ${ }^{, 37}$ Once again, Iolo's work ran counter to the prevailing climate. In these years, nonconformity spread rapidly throughout Wales, with the number of dissenting chapels rising from 1,300 in 1805 to 3,800 in 1851 , the equivalent of one new chapel opening each week; by the Religious Census of 1851, almost 80 per cent of those who said they attended a place of worship in Wales frequented nonconformist chapels. ${ }^{38}$ The overwhelming majority of the new chapels were Methodist or Baptist, and their congregations favoured the intense emotional style of the leading Welsh hymn writer of this (or any other) period, the Methodist William Williams Pantycelyn (1717-91), whose best-known hymn was translated into English as "Guide me, O thou great Jehovah, / Pilgrim through this barren land." By contrast, while the first edition of Iolo's hymns, consisting of 500 copies, "went off in little more than three months," their audience was confined within "the boundaries of our South Wales Unitarian connexion., 39

In both his English songs and Welsh hymns, Iolo evinces a commitment to a "rational" model of song. Poems, Lyric and Pastoral includes "an attempt to write a rational drinkingsong," written as early as 1785 "for the use of a little select society of journeymen masons, that met weekly to spend a chearful Hour at the moderate, and restricted, expence of fourpence." There is no tune given, so we are left to infer the qualities of "a rational drinking-song" from the lyrical content, which emphasizes sobriety, vocal and ideological harmony, and staunch political independence:

Whilst Mirth and good ale our worn spirits recruit, We'll Drunk'ness avoid, that delight of a brute:

\footnotetext{
${ }^{37}$ Butler, Mapping Mythologies, 153.

${ }^{38}$ James, "Evolution of the Welsh Hymn," 229.

${ }^{39}$ Iolo Morganwg to Lant Carpenter, Keven Cribor, 6 July 1818, Correspondence, III, 474; Iolo Morganwg to William Williams, 19 February 1812, Correspondence, III, 104.
} 
Of matters of State we'll have nothing to say,

Wise Reason shall rule, and keep Discord away.

Whilst, tuning our voices, Jocundity sings,

Good fellows we toast, and know nothing of Kings... ${ }^{40}$

Iolo's hymns are similarly intended to be the vehicles of a rational faith, aiming for "a more rational manner, a style of purer simplicity and greater purity of language than what we find in our numerous volumes of Welsh hymns, where we find nothing but enthusiastic rants in the language, nonsensical sectarianism, chiefly Calvinism in, I may say, the language of madness, with respect to doctrine, sentiment, expression, \&c." "I1 "I do not entirely approve of the use of music in parts," Iolo wrote, seeing it as a bar to participation, as a form of elboration that compromises the affective power of unison singing: "I, for my own part, would recommend that the melody only, without any accompaniment should be sung" ${ }^{42}$ This desire for simplicity extended to the lyrical content: as Ffion Mair Jones has shown, Iolo was especially keen to reject the extravagant metaphors that characterize Pantycelyn's writing, in favour of a plainer style. ${ }^{43}$ The belief in the potential for rational song is, then, a feature that runs through Iolo's secular and sacred compositions, in an attempt to reclaim song from its associations with enthusiasm and unreason.

Alongside this project, Iolo began to collect traditional melodies, in collaboration with the antiquarians Joseph Ritson and William Owen Pughe. Iolo's vast archive, which he described as a "terrible mound of trifling scraps," is filled with songs and song tunes on tiny slips of paper, many labelled as (for example) "South Walian tune," "psalm tune" or "hymn tune," suggesting a compulsive approach to writing and taking down melodies. This is perhaps the area of Iolo's output that has proved most resistant to critical interpretation. Among these papers are sixty

\footnotetext{
${ }^{40}$ Iolo Morganwg, Poems, Lyric and Pastoral, II, 80, 83-4.

${ }^{41}$ Iolo Morganwg to George Dyer, Glamorgan, 15 February 1811, Correspondence, III, 55-6.

${ }^{42}$ Iolo Morganwg to Lant Carpenter, Keven Cribor, 6 July 1818, Correspondence, III, 474.

${ }^{43}$ Ffion Mair Jones, “The Bard is a Very Singular Character,” 207.
} 
"Ancient popular melodies collected in South Wales," some with words, as well as popular songs without tunes. As Daniel Huws writes, these "earn Iolo credit as the first collector of Welsh folksongs.. ${ }^{44}$ They seem to have been collected as the raw materials of his projected magnum opus, "The History of the Bards," which was to include among its many topics a history of Welsh music, and convey some clues into Iolo's method as a song collector and protoethnomusicologist. To take one example, "Symlen ben bys, as in Glamorgan, an Old Welsh Tune" (Figure 4) is a six-bar melody, neatly copied down, its notation and minimal rhythmic variation resembling medieval plainchant. There is no key signature and no evidence of the kind of "correction" or harmonization typical of later song collectors. Beneath the stave, Iolo writes, "The following, said to be a North American Indian Tune is remarkably like the above old Welsh tune. The metre adapted to this Tune is one of the most common metres in Wales and also in Scotland, and not uncommon in England." After a further six bars, very similar to the first, Iolo attempts to account for their resemblance:

The Welsh Tune is from a MS prior to the discovery of America by Columbus, and if the Indian Tune is authentic, this must be allowed to be a most wonderful coincidence, not only in the music, but also in the metre and verse to which both tunes are equally adapted. A Gentleman who has been many years in the East Indies assures me that he has heard it sung by the Hindoos and Persians on the Coast of Malabar, who also play it on an instrument on a principle not unlike the violin or guittar of Europe. I know of no better way of accounting for this than by supposing it to have been an old tune commonly known by the English as well as the Welsh, common, perhaps, to every part of Britain, possibly to all Europe, and that Englishmen, or other Europeans, took it over to both America and India, very soon after the discovery of the latter part of the world by Columbus, and of the way round the cape of good hope to India, and that from such persons the Indians in both parts of the world learned this simple tune. ${ }^{45}$

Huws has questioned the veracity of this account, pointing out that Iolo must have known "Symlen ben bys" through its inclusion in Edward Jones's Musical and Poetical Relicks of the

\footnotetext{
${ }^{44}$ Huws, "Iolo Morganwg and Traditional Music", in Jenkins (ed.), A Rattleskull Genius.

45 "Symlen ben bys, as in Glamorgan, an Old Welsh Tune." Iolo Morganwg manuscripts and papers, National Library of Wales, E1 / 1 / 17A.
} 
Welsh Bards. This might lead us to read the tune as a fake antique, included to corroborate what James Mulholland has described as Iolo's "aboriginal aesthetics": his belief "that the Welsh were the aborigines, the original people of the world," involving "a type of racism that distinguishes Welsh aboriginals from the 'state of nature' popularized by Rousseau or the primitivist paradises that appeared in travel narratives of Tahiti and other Pacific islands." For Mulholland, Iolo's selfpresentation rested on an image of himself as "the conduit by which the pure Welsh past could become audible, a past unadulterated by foreign customs and myths." ${ }^{, 46}$ The argument on this manuscript, however, is not for Welsh exceptionalism or nativism; instead, Iolo suggests the tune was known across Britain, "possibly to all Europe," and exported across America and India through the mechanisms of colonial expansion. In the shadow of empire, Iolo re-affirms his faith in the universality of song as it moves across borders, rapidly shedding markers of national belonging. Far from being reducible to a form of Welsh chauvinism, Iolo's identity as a song and show man extends to a belief in song as a vehicle of the radical Enlightenment, one that is able to channel reason and penetrate systems of religious and political mystification.

Figure 1: Draft of Iolo's 'God Save the King', later published in Poems, Lyric and Pastoral (1794). Iolo Morganwg manuscripts and papers, National Library of Wales, MS 21392F / 6v.

Figure 2: 'Trial by Jury, The Grand Palladium of British Liberty.' Iolo Morganwg manuscripts and papers, National Library of Wales, MS 21401E / 32.

\footnotetext{
${ }^{46}$ Mulholland, Sounding Imperial: Poetic Voice and the Politics of Empire, 1730-1820 (Baltimore: Johns Hopkins University Press, 2013), 75-7.
} 
Figure 3: 'Song, written, and set to music, by Edward Williams, for the celebration of the Trial by Jury.' Iolo Morganwg manuscripts and papers, National Library of Wales, E3 (i) 54.

Figure 4: 'Symlen ben bys, as in Glamorgan, an Old Welsh Tune'. Iolo Morganwg manuscripts and papers, National Library of Wales, E1 / 1 / 17A.

\section{Bibliography}

Anderson, Misty G. Imagining Methodism in Eighteenth-Century Britain: Enthusiasm, Belief \& the Borders of the Self. Baltimore: Johns Hopkins University Press, 2012.

Barlow, Rachelle. "The 'Land of Song': Gender and Identity in Welsh Choral Music, 1872-1918" Unpublished Cardiff University PhD dissertation, 2015.

Butler, Marilyn. Mapping Mythologies: Countercurrents in Eighteenth-Century Poetry and Cultural History. Cambridge: Cambridge University Press, 2015.

Constantine, Mary-Ann, and Elizabeth Edwards. “'Bard of Liberty': Iolo Morganwg, Wales and Radical Song', in John Kirk, Andrew Noble and Michael Brown (eds), United Islands?: The Languages of Resistance. London: Pickering \& Chatto, 2012.

Charnell-White, Cathryn. Bardic Circles: National, Regional and Personal Identity in the Bardic Vision of Iolo Morganwg. Cardiff: University of Wales Press, 2007.

Collected Letters of Samuel Taylor Coleridge: Volume I, ed. Earl Leslie Griggs. Oxford: Clarendon Press, 1956.

Constantine, Mary-Ann. The Truth Against the World: Iolo Morganwg and Romantic Forgery. Cardiff: University of Wales Press, 2007.

Constantine, Mary-Ann. “The Relicks of Edward Jones," Romantic National Song Network, ed. Kirsteen McCue $<\underline{\text { https://rnsn.glasgow.ac.uk/the-relicks-of-edward-jones/>. }}$

Cox Jensen, Oskar. Napoleon and British Song, 1797-1822. Basingstoke: Palgrave Macmillan, 2015. 
Edwards, Elizabeth. “'Lonely and Voiceless Your Halls Must Remain': Romantic-Era National Song and Felicia Hemans's Welsh Melodies (1822)", Journal for Eighteenth-Century Studies, 38.1 (2015), 83-97.

Grande, James. "On Tongues and Ears: Divine Voices in the Modern Metropolis," in Roger Parker and Susan Rutherford (eds), London Voices, 1820-1840: Performers, Practices, Histories. Chicago: University of Chicago Press, 2019.

Hazlitt, William. "On the Tendency of Sects," The Complete Works of William Hazlitt, 21 vols, ed. P.P. Howe. London: J.M. Dent, 1930-4.

Huws, Daniel. "Iolo Morganwg and Traditional Music”, in Geraint H. Jenkins (ed.), A Rattleskull Genius.

James, E. Wyn. "The Evolution of the Welsh Hymn”, in Rivers and Wykes (eds), Dissenting Praise.

Jenkins, Bethan M. Between Wales and England: Anglophone Welsh Writing of the Eighteenth Century. Cardiff: University of Wales Press, 2017.

Jenkins, Geraint H. (ed.). A Rattleskull Genius: The Many Faces of Iolo Morganwg. Cardiff: University of Wales Press, 2005.

Jenkins, Geraint H, Ffion Mair Jones and David Ceri Jones (eds). The Correspondence of Iolo Morganwg, 3 vols. Cardiff: University of Wales Press, 2007.

Jenkins, Geraint H. Bard of Liberty: The Political Radicalism of Iolo Morganwg. Cardiff: University of Wales Press, 2012.

Johnston, Kenneth R. Unusual Suspects: Pitt's Reign of Alarm and the Lost Generation of the 1790s. Oxford: Oxford University Press, 2013.

Jones, Edward. Musical and Poetical Relicks of the Welsh Bards. London, 1784.

Jones, Edward. The Bardic Museum, of Primitive British Literature. London, 1802.

Jones, Emrys (ed.). The Welsh in London, 1500-2000. Cardiff: University of Wales Press, 2001.

Jones, Ffion Mair. "The Bard is a Very Singular Character”: Iolo Morganwg, Marginalia and Print Culture. Cardiff: University of Wales Press, 2010.

Langan, Celeste, 'Scotch Drink \& Irish Harps: Mediations of the National Air', in Phyllis Weliver (ed.), The Figure of Music in Nineteenth-Century British Poetry. Aldershot: Ashgate, 2005.

McAulay, Karen. Our Ancient National Airs: Scottish Song Collecting from the Enlightenment to the Romantic Era. Farnham: Ashgate, 2013. 
Mee, Jon. Dangerous Enthusiasm: William Blake and the Culture of Radicalism in the 1790s. Oxford: Clarendon Press, 1992.

Mee, Jon. “"'Images of Truth New Born”: Iolo, William Blake and the Literary Radicalism of the 1790s", in Geraint H. Jenkins (ed.), A Rattleskull Genius.

Morganwg, Iolo. Poems, Lyric and Pastoral, 2 vols. London, 1794.

Mulholland, James. Sounding Imperial: Poetic Voice and the Politics of Empire, 1730-1820. Baltimore: Johns Hopkins, 2013.

Newman, Ian. The Romantic Tavern: Literature and Conviviality in the Age of Revolution. Cambridge: Cambridge University Press, 2019.

Rimmer, Joan. "Edward Jones's Musical and Poetical Relicks of the Welsh Bards, 1784: A ReAssessment", The Galpin Society Journal, 39 (1986), 77-96.

Rivers, Isabel, and David L. Wykes (eds). Dissenting Praise: Religious Dissent and the Hymn in England and Wales. Oxford: Oxford University Press, 2011.

Schmidt, Leigh Eric. Hearing Things: Religion, Illusion, and the American Enlightenment. Cambridge, Mass.: Harvard University Press, 2000.

Southey, Robert. Madoc, 2 vols. London, 1805.

Thompson, E.P. The Making of the English Working Class. London: Victor Gallancz, 1963.

Trumpener, Katie. Bardic Nationalism: The Romantic Novel and the British Empire. Princeton: Princeton University Press, 1997.

Walford Davies, Damian. Presences That Disturb: Models of Romantic Identity in the Literature and Culture of the 1790s. Cardiff: University of Wales Press, 2002.

Walford Davies, Damian, and Lynda Pratt (eds). Wales and the Romantic Imagination. Cardiff: University of Wales Press, 2007.

White, Daniel E. Early Romanticism and Religious Dissent. Cambridge: Cambridge University Press, 2006.

Williams, Gareth. Valleys of Song: Music and Society in Wales, 1840-1914. Cardiff: University of Wales Press, 1998. 